\title{
THE PHILOSOPHY OF TRANSHUMANISM
}


This page intentionally left blank 


\title{
THE PHILOSOPHY OF TRANSHUMANISM
}

\author{
A Critical Analysis
}

BENJAMIN ROSS

University of North Texas, USA

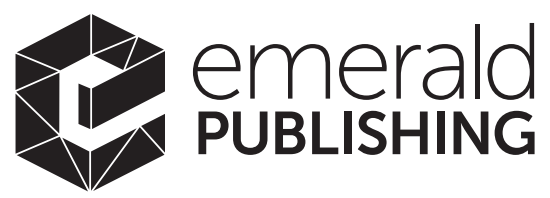

United Kingdom - North America - Japan - India Malaysia - China 
Emerald Publishing Limited

Howard House, Wagon Lane, Bingley BD16 1WA, UK

First edition 2020

(C) 2020 Benjamin Ross

Published under exclusive licence by Emerald Publishing Limited

Reprints and permissions service

Contact: permissions@emeraldinsight.com

No part of this book may be reproduced, stored in a retrieval system, transmitted in any form or by any means electronic, mechanical, photocopying, recording or otherwise without either the prior written permission of the publisher or a licence permitting restricted copying issued in the UK by The Copyright Licensing Agency and in the USA by The Copyright Clearance Center. Any opinions expressed in the chapters are those of the authors. Whilst Emerald makes every effort to ensure the quality and accuracy of its content, Emerald makes no representation implied or otherwise, as to the chapters' suitability and application and disclaims any warranties, express or implied, to their use.

British Library Cataloguing in Publication Data

A catalogue record for this book is available from the British Library

ISBN: 978-1-83982-625-2 (Print)

ISBN: 978-1-83982-622-1 (Online)

ISBN: 978-1-83982-624-5 (Epub)

ISOQAR certified

Management System,

awarded to Emerald

for adherence to

Environmental

standard

ISOQAR

ISO 14001:2004.

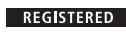

Certificate Number 1985

ISO 14001

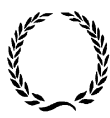

INVESTOR IN PEOPLE 


\section{CONTENTS}

Introduction

1. Redesigning Humans 5

1. 1. Transhumanist Philosophy I: Summoning the Posthuman 7

1.2. Transhumanist Philosophy II: Epistemological Certainty 13

1.3. Resisting Transhumanism: Bioconservative Views 18

1.4. The Language of Enhancement through the Lens of Automation

2. Engaging with Transhumanism 37

2.1. The Three Supers of Transhumanism 38

2.2. Mythic and Religious Precursors to Transhumanism 43

2.3. Modern Philosophy and the Emergence of Transhumanism

2.4. Science Fiction: Transhumanism in the Cultural Imagination

2.5. Realizing Transhumanism: Contemporary Institutions

3. Living "Forever": Transhumanism and Mortality 73

3.1. Human Immortality as Amortality 75

3.2. The Ontology of Amortality 80

3.3. Social-Political and Metaphysical Concerns Raised by Amortality 89

4. "Unlimited" Intelligence and Well-being 99

4.1. Questioning the Emergence of Superintelligence 101 
4.2. Faith in Superintelligence: An Inevitable Singularity? 106

4.3. Engineering a Perfect World: Infinite Well-being 115

4.4. Problematizing Transhuman Hedonism 119

5. The Role of the Philosopher in Transhumanism 127

5. 1. The Overhuman: Proto-transhumanism or Critique?

5.2. Questioning Cyborg Values

5.3. Nietzsche's Philosophy: The Revaluation of Values

6. Transhumanism and Buddhist Philosophy: Two Approaches to Suffering

6.1. Deconstructing the Self versus Enhancing the Self

6.2. Failing to "Empty" Emptiness: Deconstruction as Reification

6.3. Buddhist Philosophy as an Alternative to Transhumanism?

Conclusion: Contesting and Considering

Transhumanism

References

Index 